\title{
Perbandingan Akurasi Analisis Sentimen Tweet terhadap Pemerintah Provinsi DKI Jakarta di Masa Pandemi
}

\author{
Ragil Dimas Himawan ${ }^{\# 1}$, Eliyani ${ }^{* 2}$ \\ \#Program Studi Informatika Fakultas Ilmu Komputer, Universitas Mercu Buana \\ Jl. Meruya Selatan No. 1, Kembangan, Jakarta 11650

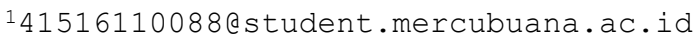 \\ ${ }^{3}$ eliyani@mercubuana.ac.id
}

\begin{abstract}
Abstrak- Pemerintah memanfaatkan media sosial seperti twitter sebagai salah satu kanal interaksi dengan masyarakat. Informasi hasil interaksi tersebut sebagai umpan balik untuk mengetahui opini masyarakat terhadap kebijakan publik. Analisis sentimen tweet dari masyarakat dapat dijadikan sebagai salah satu parameter penunjang bagi pemerintah dalam mengevaluasi kebijakan dan pengambilan keputusan mendatang. Penelitian ini bertujuan untuk mengetahui sentimen data tweet masyarakat terhadap akun twitter resmi Pemerintah Provinsi DKI Jakarta di masa pandemi COVID19. Data yang diperoleh sebanyak 14208 baris dengan query pada tweet yang mengandung kata atau menyebut username @ dkijakarta, dimana akan dikelompokkan berdasarkan kelas sentimen yaitu, negatif, netral, dan positif dengan menggunakan $T F-I D F$ Vectorizer untuk pembobotan kata dan klasifikasi menggunakan beberapa metode yaitu, random forest classifier dengan hasil akurasi sebesar 75,81\%, algoritma naive bayes dengan hasil akurasi $75,22 \%$, dan algoritma support vector machine $\mathbf{7 7 , 5 8 \%}$. Dilakukan proses analisis sentimen pada tweet dengan presentase hasil negatif, netral, dan positif masing-masing yaitu, $8,8 \%, 83,6 \%, 7,6 \%$.
\end{abstract}

Kata kunci- Analisis Sentimen, Twitter, Text Mining, TFIDF, Klasifikasi, Support Vector Machine, Nä̈ve Bayes, Random Forest Classifier

\section{Pendahuluan}

Perkembangan teknologi internet telah membuat penyebaran informasi meningkat secara signifikan. Salah satu yang mendukung penyebaran informasi tersebut adalah media sosial. Pengguna media sosial bukan hanya sebagai konsumen informasi, tetapi juga sebagai penghasil informasi[1]. Salah satu media sosial dengan pengguna terbanyak adalah twitter. Indonesia memiliki jumlah pengguna aktif twitter yang tinggi[2]. Hal ini berdampak pula pada tingginya jumlah data tweet yang dihasilkan. Berbagai peristiwa atau topik terkini menjadi pemicu bagi setiap pengguna untuk melakukan tweet.

Berbagai instansi pemerintahan sudah memiliki akun twitter resmi yang digunakan sebagai kanal interaksi antara masyarakat dan pihak pemerintah[3]. Salah satunya adalah
Pemerintah Provinsi DKI Jakarta dengan username @dkijakarta. Melalui twitter, masyarakat dapat mengutarakan opini mengenai kebijakan pemerintah, mengajukan pertanyaan mengenai pelayanan publik, ataupun sekadar berkomentar untuk bersosialisasi antar masyarakat.

Coronavirus disease 2019 atau COVID-19 ditetapkan secara resmi oleh Organisasi Kesehatan Dunia sebagai pandemi global pada 11 Maret 2020[4], berbagai kebijakan diambil oleh Pemerintah Provinsi DKI seperti Pembatasan Sosial Berskala Besar atau PSBB yang mulai berlaku pada 10 April 2020. PSBB mencakup hal terkait kegiatan perekonomian, keagamaan, sosial, budaya dan pendidikan di Jakarta[5]. PSBB secara tidak langsung berpengaruh terhadap perilaku masyarakat untuk mengurangi interaksi secara langsung antar individu. Twitter merupakan media sosial yang banyak digunakan masyarakat saat pandemi.

Sumber data penelitian ini berasal dari tweet masyarakat terhadap akun twitter Pemerintah Provinsi DKI Jakarta di masa pandemi untuk dilakukan klasifikasi dalam menentukan sentimen. Pada penelitian terkait sebelumnya[6], akurasi metode Naive Bayes lebih baik dibandingkan dengan $k$-Nearest Neighbor(k-NN). Penelitian lainnya[7] menggunakan support vector machine pada dua dataset dengan topik berbeda yaitu selfdriving car dan produk apple. Akurasi yang dihasilkan masing-masing sebesar 59,91\% dan 71,2\%. Penelitian yang lain[8] didapatkan skenario terbaik dengan teknik klasifikasi support vector machine menggunakan pembobotan kata TF-IDF dan stemming.

Pada penelitian ini data diambil dengan teknik crawling menggunakan API Twitter pada rentang waktu 9 April 2020 sampai 15 April 2020. Metode yang digunakan yaitu support vector machine, naïve bayes, dan random forest classifier dengan TF-IDF Vectorizer dan proses stemming bahasa Indonesia. Metode dengan model terbaik akan digunakan untuk memprediksi sentimen pada data yang kosong. 


\section{LANDASAN TEORI}

\section{A. Analisis Sentimen}

Analisis sentimen adalah metode komputasional untuk mengekstraksi dan menganalisis sentimen pada suatu entitas dan atribut yang dimiliki[9][10]. Pada umumnya menggunakan metode dengan pendekatan machine learning berbasis teks.

\section{B. Text Mining}

Text mining merupakan proses penemuan pengetahuan menggunakan Natural Language Processing (NLP) dengan cara menggali informasi dari sebuah data berformat teks[11]. Data teks bisa berupa data yang terstruktur seperti data dalam database maupun data yang tidak terstruktur seperti kumpulan dari dokumen teks.

\section{C. $T F-I D F$}

TF-IDF adalah metode pembobotan kata dengan mengekstraksi ciri dari suaru teks[12]. Terdidi dari dua aspek: (1) term frequency (TF), frekuensi sebuah term muncul dalam sebuah dokumen; (2) inversed document frequency (IDF), mengukur seberapa penting suatu term[13]. Dalam TF, semua istilah dianggap sama pentingnya. IDF adalah ukuran besarnya kepentingan term yang diimbangi dengan frekuensi suatu istilah yang muncul dalam dataset.

\section{Klasifikasi}

Klasifikasi merupakan sebuah teknik yang digunakan untuk memasukan objek ke dalam kelas-kelas sesuai dengan karakteristik kelas yang telah didefinisikan sebelumnya[14]. Proses klasifikasi berdasarkan pola yang didapatkan dari data historis yang lalu dan digunakan sebagai klasifikasi nilai yang diprediksi di masa mendatang.

\section{METODE PENELITIAN}

Pada penelitian ini terdiri dari beberapa tahapan meliputi crawling data, pra-pemrosesan data, ekstraksi fitur TF-IDF, uji klasifikasi dan hasil seperti pada Gambar 1.
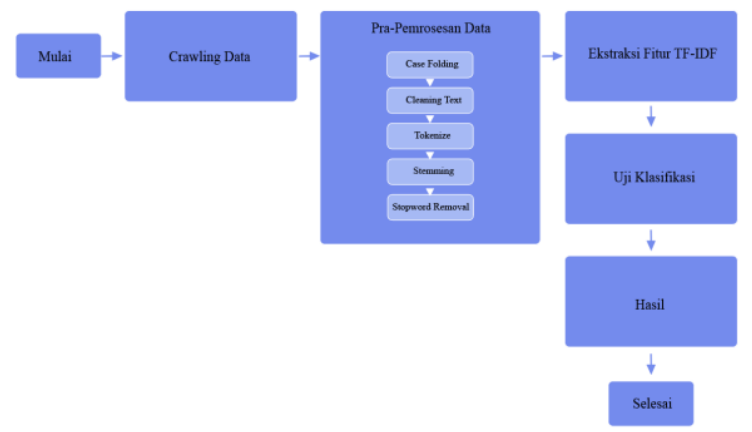

Gambar 1. Diagram kerja

\section{A. Crawling Data}

Metode pengumpulan data dilakukan dengan teknik crawling memanfaatkan API key twitter. Data diambil dengan kata kunci @dkijakarta dan difilter hanya yang berbahasa Indonesia dan bukan merupakan hasil dari retweet.

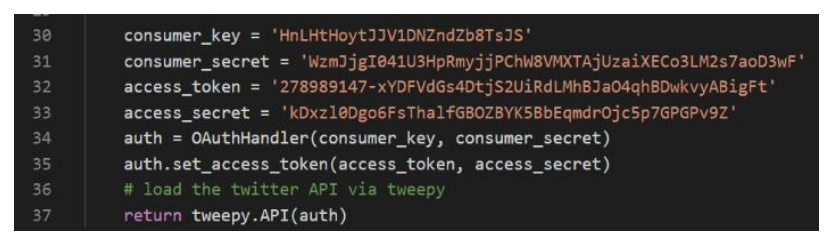

Gambar. 2 API key twitter

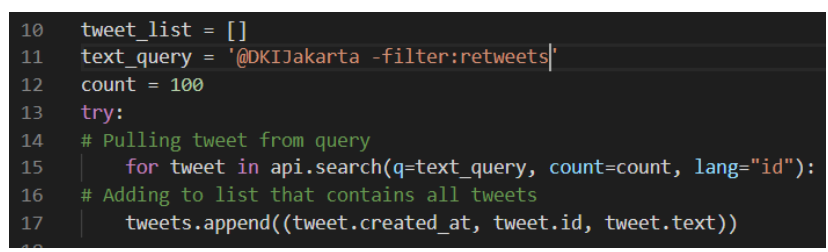

Gambar. 3 Query menggunakan fungsi api.search

\section{B. Pra-Pemrosesan Data}

Tahapan pra-pemrosesan data adalah tahap pembersihan data dan mentransformasikan data teks menjadi lebih terstruktur. Tahapan ini diperlukan untuk meningkatkan kualitas data dengan menghapus data yang tidak diinginkan dari data asli[15]. Ada beberapa tahapan yang digunakan pada pra-pemrosesan data teks, yaitu :

1) Case Folding: Mentransformasi semua huruf yang ada dalam dokumen menjadi huruf kecil.

2) Cleaning text: Penghapusan karakter, simbol, username (@username), URL dan tanda baca yang tidak diperlukan.

3) Tokenize: Pemecahan dokumen teks atau kalimatkalimat yang ada ke dalam potongan-potongan kata yang disebut token.

4) Stemming: Proses stemming adalah proses transformasi sebuah kata menjadi kata dasar (root). Untuk stemming dalam bahasa Indonesia menggunakan library python sastrawi. Sastrawi merupakan library yang dapat mengubah kata berimbuhan dalam bahasa Indonesia menjadi bentuk kata dasar.

5) Stopword removal: penghapusan kata yang terdapat pada stopword list yang berisi kata-kata tidak penting atau tidak memiliki makna seperti kata hubung ataupun kata depan.

\section{C. $T F-I D F$}

TF-IDF dilakukan untuk pembobotan kata dari setiap data tweet. Rumus dari TF-IDF adalah

$$
T F=\frac{\text { Frekuensi term dalam satu dokumen }}{\text { Total kata dalam dalam satu dokumen }}
$$

$$
I D F=\log \frac{\text { Total dokumen }+1}{\text { Frekuensi dokumen mengandung term }}
$$

$$
T F-I D F=T F \times I D F
$$


Pada penilitian ini menggunakan library scikit-learn dalam implementasi TF-IDF untuk mengubah data menjadi bentuk vektor.

\section{Klasifikasi}

Ada beberapa metode klasifikasi yang digunakan:

1) Support Vector Machine (SVM): Cara kerja SVM adalah berusaha menemukan hyperplane dengan jarak antar kelas[16].

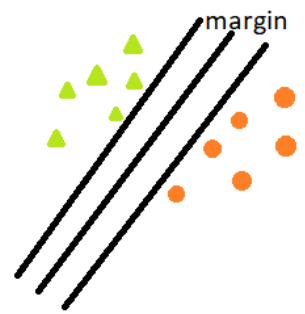

Gambar. 4 Hyperplane pada SVM

Implementasi metode SVM menggunakan salah satu class yang tersedia pada library scikit-learn yaitu, LinearSVC.

2) Nä̈ve Bayes: Metode ini menggunakan hitungan probabilitas bersyarat atau biasa dikenal dengan Teorema Bayes. Pada Text mining, jenis yang cocok dipakai adalah Multinomial Naive Bayes[17].

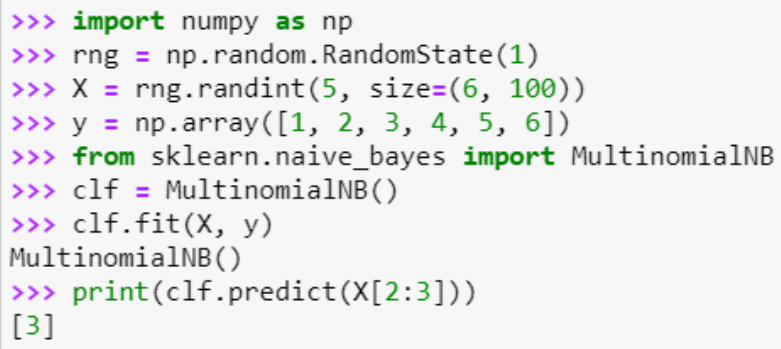

Gambar. 5 Class multinomialNB pada scikit-learn

3) Random Forest Classifier (RF): RF adalah algoritma ensemble yang merupakan kombinasi dari pohon keputusan (classifier)[18]. RF menggunakan sampling secara acak dengan distribusi yang seimbang.

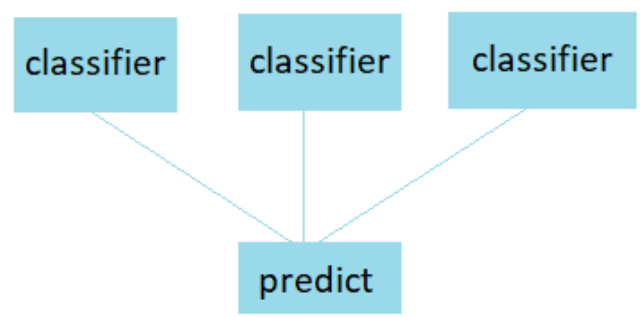

Gambar. 6 Random forest

\section{HASIL DAN PEMBAHASAN}

Data yang berhasil diambil dengan teknik crawling menggunakan API Twitter pada rentang waktu 9 April 2020 sampai 15 April 2020. Query yang digunakan adalah @ dkijakarta kemudian difilter berdasarkan Bahasa Indonesia dan tweet yang bukan merupakan hasil dari retweet menghasilkan 14208 baris data.

\begin{tabular}{|c|c|c|}
\hline Tanggal & text & screen name \\
\hline $4 / 15 / 2020$ & $\begin{array}{l}\text { @DKIJakarta Pemimpin kw itu ketika urusan formal di } \\
\text { omongin via MEDSOS!!! } \\
\text { Ketularan berobat ONLINE }\end{array}$ & BangDama \\
\hline $4 / 15 / 2020$ & $\begin{array}{l}\text { yg masih menyuruh datang ke tempat kerja nya, padahal } \\
\text { pemprov DKI... https://t.co/HVAwkVfYS7 }\end{array}$ & Heru22003036 \\
\hline $4 / 15 / 2020$ & $\begin{array}{l}\text { @DKIJakarta Kl di daerah cakung, boleh buka tapi } \\
\text { dibawa pulang . Jd gak ada bangku buat mkn }\end{array}$ & Dodi76650439 \\
\hline $4 / 15 / 2020$ & $\begin{array}{l}\text { tindakan kepada warga yang masih nongkrong \&gt;5 orang } \\
\text { di daerah Jal... https://t.co/Ud0ywMJ18V }\end{array}$ & retnowiryawan \\
\hline $4 / 15 / 2020$ & jamet, nyaut ngape lo... & jajaka666 \\
\hline
\end{tabular}

Gambar. 7 Hasil crawling

Setelah mendapatkan data hasil crawling dan dijadikan sebuah dataset, tahap selanjutnya adalah proses pelabelan pada sebagian data untuk membagi kelas sentimen menjadi tiga kelas, yaitu negatif, netral, dan positif. Pelabelan dilakukan secara manual untuk kemudian dibagi menjadi dua bagian, data latih dan data uji.

\begin{tabular}{l|c|c|}
\hline \multicolumn{1}{|c|}{ tweet } & username & sentimen \\
\hline $\begin{array}{l}\text { @fadjroeL @DKIJakarta Bahu } \\
\text { membahu..kerja sama yg top dech... }\end{array}$ & cueng81 & 1 \\
\hline $\begin{array}{l}\text { @DKIJakarta Semoga dengan ada } \\
\text { kebijakan ini jadi makin berkurang dan } \\
\text { memutus rantai virus }\end{array}$ & Agustina_DJ7 & \\
\#CegahBarengCOVID19 & & 1 \\
\hline $\begin{array}{l}\text { Min@DKIJakarta pengambilan } \\
\text { sembako pangan murah untuk guru KKI } \\
\text { selama PSBB dan pandemi corona }\end{array}$ & Toxy_91 & \\
bagaimana ya rules nya? & & \\
\hline $\begin{array}{l}\text { @Ghazi10415477 @DKIJakarta } \\
\text { @kominfotikJU Patrolinya } \\
\text { berbondong2..poto2 video2..ya gak } \\
\text { efektif jadinya.. }\end{array}$ & digitalmbul & \\
\hline $\begin{array}{l}\text { @KemenkesRI @DKIJakarta Selama } \\
\text { gak tegas terkait kerumunan, ya percuma } \\
\text { aja ada PSBB. }\end{array}$ & amirsyahoke & \\
\hline
\end{tabular}

Gambar. 8 Data setelah diberi label kelas sentimen

Pada Gambar 8. pelabelan kelas sentimen menggunakan angka untuk menentukan nilai kelasnya yaitu, $(-1),(0)$, dan (1), yang masing-masing mewakili kelas negatif, netral, dan positif. Tahapan selanjutnya adalah pra-pemrosesan data.

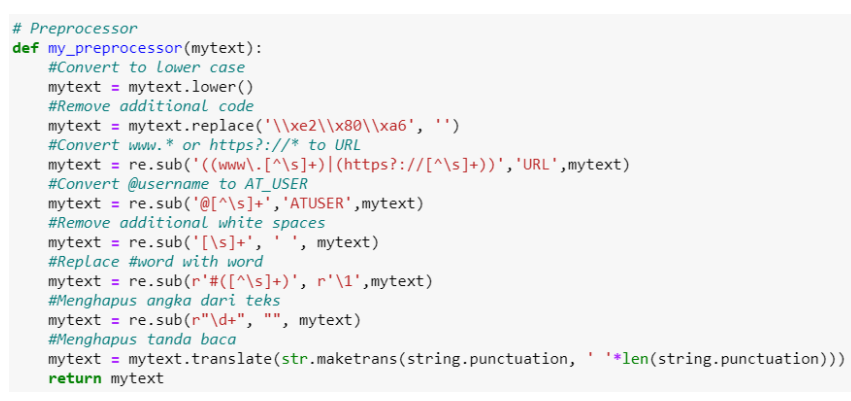

Gambar. 9 Cleaning text 
Pada Gambar 9 merupakan proses mentransformasi semua huruf menjadi huruf kecil, menghapus bentuk $U R L$ link, dan menghapus karakter serta tanda baca yang tidak diperlukan.

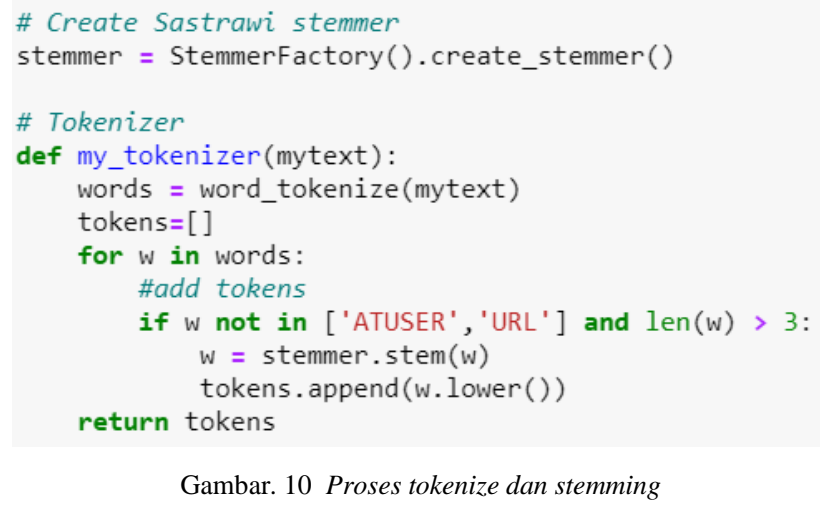

Gambar. 10 Proses tokenize dan stemming

Pada Gambar 10 dilakukan proses tokenize atau pemecahan data tweet menjadi bentuk token dengan library NLTK. Dalam proses tersebut juga dilakukan proses stemming menggunakan library sastrawi yang berfungsi untuk mengubah kata berimbuhan ke bentuk dasarnya atau yang biasa disebut root.

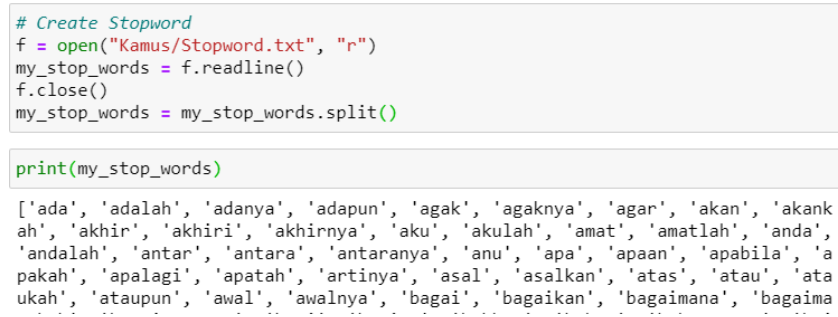

Gambar. 11 Stopword list

Stopword yang terdapat pada Gambar 11 merupakan file yang berisi kumpulan kata yang tidak penting atau kata yang tidak memiliki makna. Penghapusan stopword berguna untuk mengurangi kata yang tidak perlu diproses pada tahap feature extraction yang dapat mempengaruhi performance.

Dengan menggunakan library scikit-learn, class TfidfVectorizer dapat menghitung nilai TF-IDF sekaligus melakukan pre-processing.

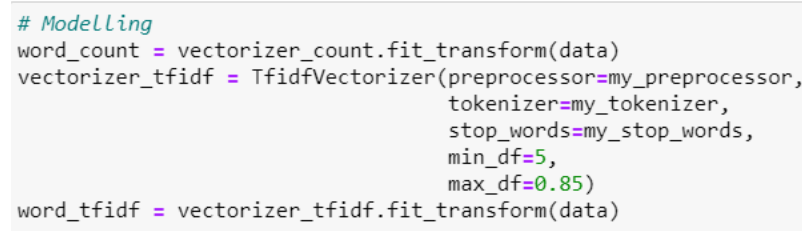

Gambar. 12 Proses TF-IDF Vectorizer

Pada Gambar 12 adalah proses TF-IDF vectorizer yang merupakan proses transformasi data teks ke dalam bentuk vektor.

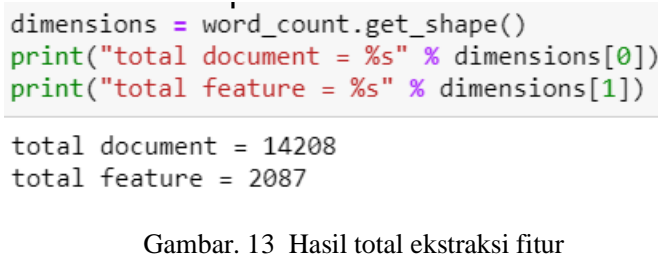

Gambar. 13 Hasil total ekstraksi fitur

Hasil total dari ekstraksi fitur yang dihasilkan dari proses TF-IDF vectorizer adalah 2087 fitur dan 14208 dokumen. Pada penelitian ini yang dimaksud dokumen adalah data tweet.

Uji klasifikasi dengan tiga metode yaitu, Random Forset Classifier, Linear SVM, dan Multinomial Nä̈ve Bayes, seperti pada Gambar 14. Hasil uji akurasi dapat dilihat pada Gambar 15. Uji validasi menggunakan 10 cross validation untuk data latih dan data uji.

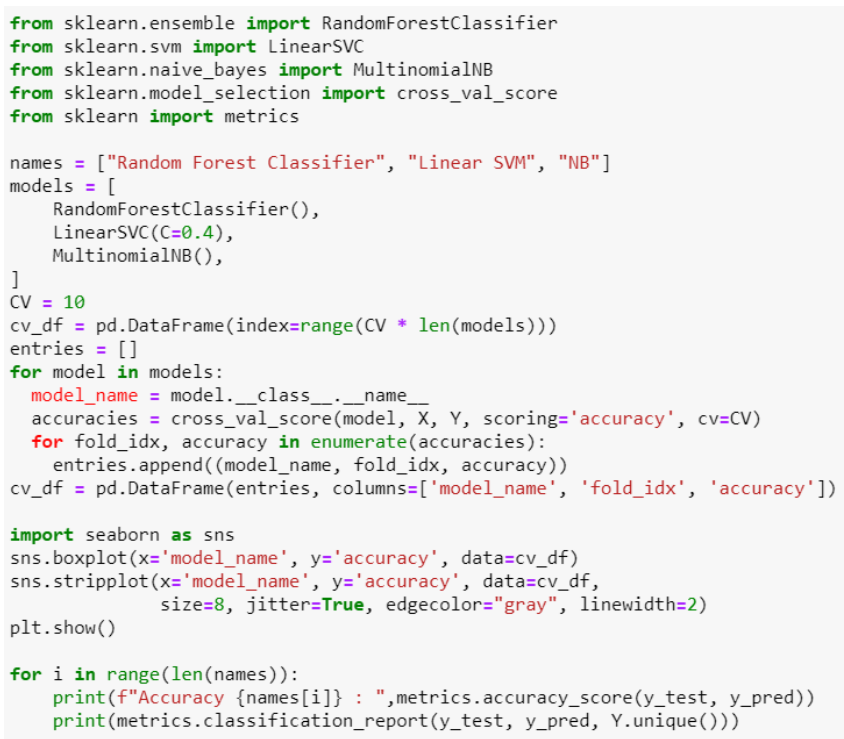

Gambar. 14 Uji model klasifikasi

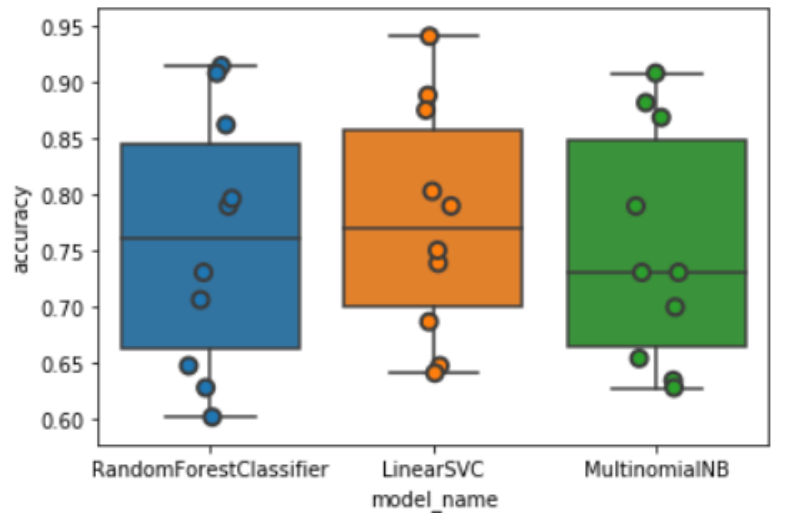

Gambar. 15 Perbandingan akurasi

Didapatkan hasil akurasi pada masing-masing model klasifikasi yaitu, Linear SVM sebesar 77,58\%, Multinomial Naive Bayes sebesar 75,22\%, dan Random Forset Classifier sebesar 75,81\%, seperti pada Gambar 16. 


\author{
model_name \\ LinearSVC \\ MultinomialNB \\ RandomForestClassifier \\ 0.775847 \\ 0.752227 \\ 0.758170 \\ Name: accuracy, dtype: float 64 \\ Gambar. 16 Nilai akurasi masing-masing metode
}

Dengan tahapan dan proses yang sama terdapat perbedaan hasil akurasi dari setiap metode untuk klasifikasi data tweet. Hal ini dikarenakan karakteristik algoritma dari setiap metode text classification. Pada penelitian ini pendekatan dengan metode linear SVM mendapatkan hasil yang terbaik.

Tahap selanjutnya adalah memprediksi nilai sentimen pada data yang masih kosong menggunakan metode Linear SVM, seperti terlihat pada Gambar 17.

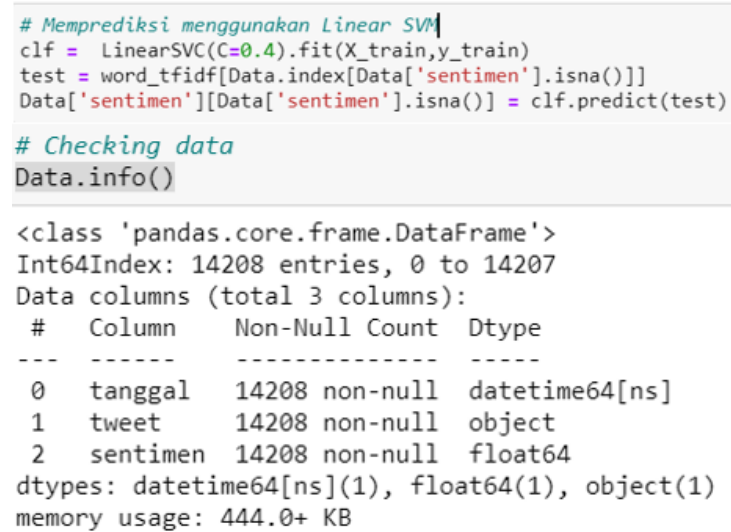

Gambar 17. Prediksi nilai sentiment

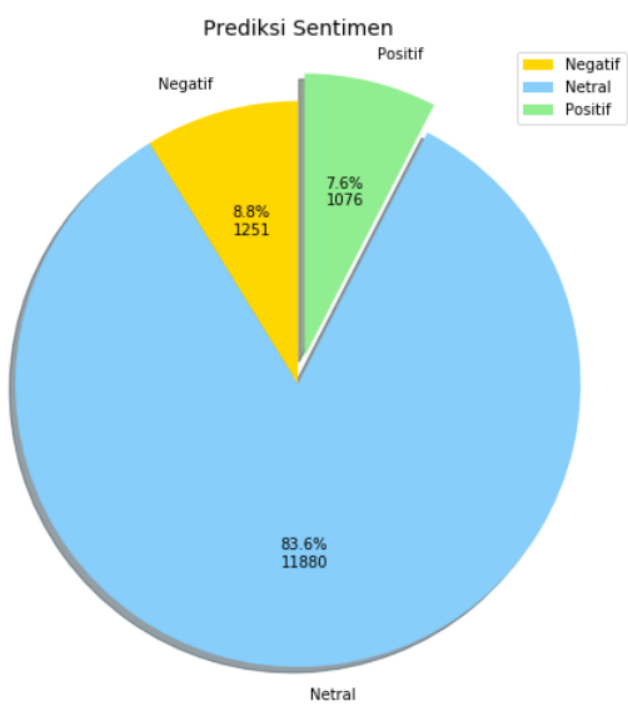

Gambar. 18 Presentase nilai sentimen

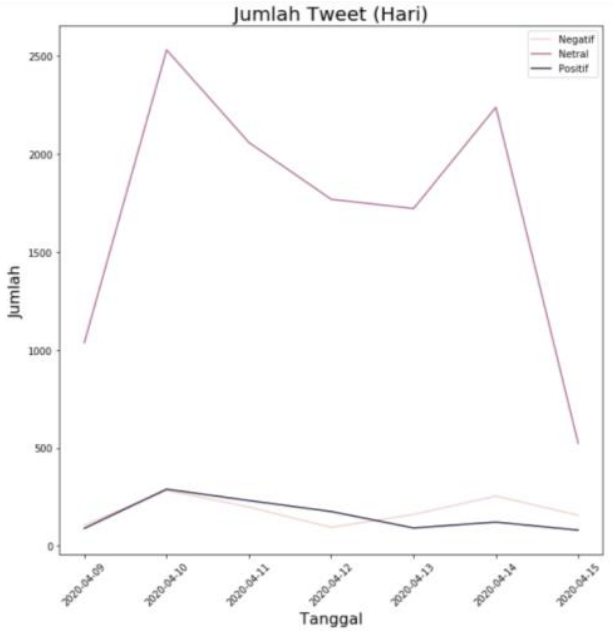

Gambar. 19 Jumlah tweet per hari

Pada Gambar 18 dan Gambar 19 dapat dilihat hasil prediksi nilai sentimen menggunakan metode linear SVM pada data yang kosong. Kelas sentimen dengan label netral memiliki presentase paling besar, 83,6\%. Dua kelas lainnya yaitu, negatif dan positif masing-masing memiliki presentase sebesar $8,8 \%$ dan $7,6 \%$

Dari Gambar 19 terlihat, jumlah tweet harian mengalami kenaikan yang signifikan pada 10 April 2020 yang merupakan hari pertama pemberlakuan kebijakan Pembatasan Sosial Berskala Besar oleh Pemerintah terkait di Jakarta.

\section{KESIMPULAN DAN SARAN}

Metode Linear SVM, Multinomial Naive Bayes, dan Random Forrest Classifier memiliki tingkat akurasi yang berbeda dalam mengklasifikasi data tweet masyarakat terhadap Pemerintah DKI Jakarta. Linear SVM memiliki akurasi terbaik dengan hasil 77,58\%, Random Forset Classifier dengan hasil $75,81 \%$, dan Multinomial Naive Bayes sebesar $75,22 \%$.

Hasil prediksi nilai kelas sentiment pada data yang kosong menggunakan algoritma Linear SVM menghasilkan prediksi netral sebesar $83,6 \%$, negative $8,8 \%$ dan positif $7,6 \%$.

Untuk penelitian yang akan datang penulis menyarankan untuk menggunakan lebih banyak data latih dan data uji agar mendapatkan nilai akurasi yang lebih tinggi. Selain itu, dapat dilakukan dengan metode atau algoritma yang dimodifikasi menjadi lebih baik.

\section{REFERENSI}

A. P. Sitorus, H. Murfi, S. Nurrohmah, and A. Akbar, "Sensing Trending Topics in Twitter for Greater Jakarta Area," vol. 7, no. 1, pp. 330-336, 2017, doi: 10.11591/ijece.v7i1.pp330-336. N. Y. A. Faradhillah, R. P. Kusumawardani, and I. Hafidz, "Eksperimen Sistem Klasifikasi Analisa Sentimen Twitter pada Akun Resmi Pemerintah Kota Surabaya Berbasis Pembelajaran Mesin (Experiments on Sentiment Classification System for Tweets of the Official Account of the City Government of Surabaya based on Mach," Pros. Semin. Nas. Sist. Inf. Indones. 2016, pp. 15-24, 2016.

[3] M. D. Anggreani, E. P. Purnomo, and A. N. Kasiwi, "RUANG PUBLIK VIRTUAL SEBAGAI PINTU KOMUNIKASI 
GOVERNMENT TO CITIZEN (Studi Kasus: Perbandingan Media Sosial Pemerintah Kota Yogyakarta dan Surabaya)," $J$. MODERAT, vol. 6, no. 1, pp. 203-220, 2020.

[4] D. Cucinotta and M. Vanelli, "WHO declares COVID-19 a pandemic," Acta Biomed., vol. 91, no. 1, pp. 157-160, 2020, doi: 10.23750/abm.v91i1.9397.

[5] W. Mas'udi and P. S. Winarti, Tata Kelola Penanganan COVID-19 di Indonesia: Kajian Awal. Jogjakarta: Gadjah Mada University Press Dilarang, 2020.

[6] A. M. Pudjajana and D. Manongga, "SENTIMEN ANALISIS TWEET PORNOGRAFI KAUM HOMOSEKSUAL INDONESIA DI TWITTER DENGAN NAIVE BAYES," vol. 9, no. 1, pp. 313-318, 2018

[7] M. Ahmad, S. Aftab, and I. Ali, "Sentiment Analysis of Tweets using SVM," Int. J. Comput. Appl., vol. 177, no. 5, pp. 25-29, 2017, doi: 10.5120/ijca2017915758.

[8] K. M. Alomari, H. M. Elsherif, and K. Shaalan, "Arabic Tweets Sentimental Analysis Using Machine Learning," vol. 1, no. June, pp. 602-610, 2017, doi: 10.1007/978-3-319-60042-0.

[9] M. Soleymani, D. Garcia, B. Jou, B. Schuller, S. F. Chang, and M. Pantic, "A survey of multimodal sentiment analysis," Image Vis. Comput., vol. 65, pp. 3-14, 2017, doi: 10.1016/j.imavis.2017.08.003.

[10] U. Rofiqoh, R. S. Perdana, and M. A. Fauzi, "Analisis Sentimen Tingkat Kepuasan Pengguna Penyedia Layanan Telekomunikasi Seluler Indonesia Pada Twitter Dengan Metode Support Vector Machine dan Lexion Based Feature," $J$. Pengemb. Teknol. Inf. dan Ilmu Komput. Univ. Brawijaya, vol. 1, no. 12, pp. 1725-1732, 2017.

[11] M. Allahyari, S. Pouriyeh, M. Assefi, S. Safei, E. D. Trippe, J. B. Gutierrez, K. Kochut, "A Brief Survey of Text Mining: Classification, Clustering and Extraction Techniques," 2017.

[12] P. H. Saputro, M. Aristin, and Dy. L. Tyas, "Klasifikasi Lagu Daerah Indonesia Berdasarkan Lirik Menggunakan Metode TFIDF dan Naive Bayes," J. Teknoloi Inform. dan Terap., vol. 4, no. 1, pp. 45-50, 2017.

[13] Z. Zhu, J. Liang, D. Li, H. Yu, and G. Liu, "Hot Topic Detection Based on a Refined TF-IDF Algorithm," IEEE Access, vol. 7, pp. 26996-27007, 2019, doi: 10.1109/ACCESS.2019.2893980.

[14] S. Dwiasnati and Y. Devianto, "Optimasi Prediksi Keputusan Calon Nasabah Potensial Berbasis Particle Swarm Optimization," Optimasi Prediksi Keputusan Calon Nasabah Potensial Berbas. Part. Swa, vol. 6, no. 2, pp. 286-292, 2019.

[15] M. Sadikin and F. Alfiandi, "Comparative Study of Classification Method on Customer Candidate Data to Predict its Potential Risk," Int. J. Electr. Comput. Eng., vol. 8, no. 6, p. 4763, 2018, doi: 10.11591/ijece.v8i6.pp4763-4771.

[16] D. Suyanto, Data Mining Untuk Klasifikasi dan Klasterisasi Data, Edisi Revi. Bandung: Penerbit Informatika, 2019.

[17] L. Jiang, S. Wang, C. Li, and L. Zhang, "Structure extended multinomial naive Bayes," Inf. Sci. (Ny)., vol. 329, pp. 346-356, 2016, doi: 10.1016/j.ins.2015.09.037.

[18] C. Coşkun, Y. Doç, and A. Baykal, "Comparison of classification algorithms in data mining on an example," vol. 116 , no. 22 , pp. 51-58, 2011. 